\title{
Variability in natural behaviour, and observed reactions to an ROV, by mid-slope fish species
}

\author{
Pascal Lorance $^{\mathrm{a}^{*}}$, and Verena M. Trenkel ${ }^{\mathrm{b}}$ \\ IIfremer, département STH, BP 70, 29280 Plouzané, France \\ ${ }^{\mathrm{b}}$ Ifremer, département EMH, rue de l'île d'Yeu, BP 21105, 44311 Nantes cedex 03, France \\ *: Corresponding author : Pascal Lorance, Ifremer, département STH, BP 70, 29280 Plouzané, France. Tel.: +33 \\ 298224649; fax: +33 298224653. pascal.lorance@ifremer.fr
}

\begin{abstract}
The behaviour of eight large benthopelagic fish taxa was analysed using video records collected with an ROV on the mid-slope of the Bay of Biscay. The studied species were roundnose grenadier (Coryphaenoides rupestris), orange roughy (Hoplostethus atlanticus), deep-sea scorpionfish (Trachyscorpia cristulata echinata), and black scabbardfish (Aphanopus carbo), as well as individuals belonging to the families Alepocephalidae, Chimaeridae, and Scyliorhinidae, and to the order Squaliformes. Some of the observed fish were grouped at the family taxonomical level due to visual identification to species being unreliable. Assumed natural (undisturbed) behaviour was categorised in terms of (i) body position with respect to the bottom sea floor, (ii) locomotion and (iii) activity type. Reaction (disturbed) behaviour to the approaching ROV was categorised in terms of reaction type and distance. Environmental conditions (depth, temperature, current speed and direction) and observation conditions (ROV speed and altitude) were recorded simultaneously with fish observations in order to explain the variability in the observed reaction behaviour. A multivariate analysis identified three groups corresponding to a behaviour pattern of a sit and wait strategist (one species), an active bottom hunter (three taxa), and a group of species displaying little activity in their bottom habitat (three taxa). At species level the environmental and observation conditions had some explanatory power for individual behaviour variability. It is hypothesised that the varied behaviour of mid-slope benthopelagic fish contributes to maintain a high species diversity of large predators in an energy poor environment.
\end{abstract}

Keywords: Bay of Biscay; Behaviour; Continental slope; Diversity; Fish; Life strategies; ROV 


\section{Introduction}

Species richness of near bottom deep-sea fish displays a maximum at mid-slope depths, from about 750 to 1500 m (Gordon 1986; Haedrich and Merrett 1988). The disturbance theory postulates that species diversity is the result of a trade off between intensity and frequency of disturbance and system productivity (Huston 1994). Applying this theory to the deep-sea (from the shelf break to the abyss), which is generally characterised by low disturbance and low productivity, intermediate species diversity might be predicted. However, the deep-sea environment is rather homogenous at a large spatial scale allowing individuals to disperse without encountering physical boundaries. This lack of boundaries, in conjunction with local adaptations triggered by paleoclimatic events (White 1988), might have resulted in the somewhat conflicting arrangement that at a local scale numerous deep-sea fish species co-occur, while at a global scale species diversity of the deep-sea is not particularly high (Merrett and Haedrich 1997). Furthermore, the low productivity of the deep-sea ecosystem is believed to have led to morphological and life history adaptations. Most deep-sea fishes are long lived with low growth rates, and display adaptations to low energy consumption (Cailliet et al 2001). This results in a striking diversity of morphologies (Merrett and Haedrich 1997). Examples of these adaptations are the large eyes providing visionary aid, neutral buoyancy for maintaining position without energy expense and prominent sensorial organs such as a large bony head or prominent lateral line (Collin and Partridge 1996; Merret and Haedrich 1997; Wagner 2002). Diversity in morphological adaptations may have its counterpart in behavioural characteristics. This study provides evidence for this hypothesis.

Deep-sea fish behaviour is currently poorly described. Some knowledge of fish position in the water column, foraging strategy and general behaviour has been inferred from morphology, anatomy, and the diet of captured individuals (Mauchline and Gordon 1986, and literature therein). Limitations to these indirect observations are obvious. Studying natural behaviour of marine species demands dedicated observations, and for those found at great depths, advanced complex technology is required to carry out this work. As well, different methods of observations provide information on different aspects of natural behaviour. Experiments using baited landers allow an assessment of foraging behaviour and swimming speed (Bailey and Priede 2002). Acoustic measurements can determine diel vertical migrations of groups or, in some particular conditions, of individuals, without providing species identification. However we note that in recent times species specific target strength data has become available to improve on the acoustic identification and behaviour of certain deep-sea fish (Simmonds \& MacLennan 2005). Archival tags provide information on small scale vertical and horizontal migrations (Sibert et al 2003; Muysl et al 2003).

Finally in situ visual observations using such tools as cameras, submersibles, and remotely operated vehicles (ROV's), provide an insight into small-scale fish distributions, their relationship with local conditions, and information on individual behaviour by species (although we note that with the presence of these tools natural behaviour is affected). While previous in situ visual observation work has primarily been dedicated to relatively small species behaviour, research has also focused on 
observing some of the large deep-sea species discussed in this paper (Lorance et al. 2002; Uiblein et al. 2002, 2003). This earlier research has provided some of the first insights into the diversity and flexibility of slope species behaviour using observations from a submersible. In this study, we build on this earlier work to test three hypotheses (1) large predators of the deep-sea fish community display speciesspecific behaviour, (2) differences in natural behaviour imply differences in reaction behaviour to disturbance, here created by an ROV, (3) large deep-sea predators adjust their behaviour to the temporal variability of the deep-sea environment. To this end, data on environmental conditions and videos of fish behaviour of eight large mid-slope fish taxa were recorded simultaneously on the continental slope of the Bay of Biscay, north-east Atlantic.

The environmental conditions in the Bay of Biscay are diverse. The topography of the seabed is mainly rugged with canyons and ridges alternating with hard cliff faces. Flat slope areas are restricted to a few small terraces. Depending on their location, the bottom of canyons can accumulate thick layers of sediment material or display rocky bottoms and erosion facies. Fish abundance over the rough bottom area is poorly known as most of the area is unsuitable for bottom trawling. On the trawlable terraces, the fish density appears very low, but it is uncertain whether these observations reflect the overall fish density in the Bay of Biscay. Limited data suggest fish density patchiness is related to small-scale topography and hydrological conditions (Lorance et al. 2002; Trenkel et al. 2004a). In terms of hydrology, the studied depths in the Bay of Biscay between 1100-1500 m, are characterised by the rather saline and warm (5 to $9.5^{\circ} \mathrm{C}$ ) Mediterranean waters influencing the region (Vangriesheim 1985). Three sites were sampled in the same depth range over several tidal cycles in order to repeat sampling over depth, temperature and current speed ranges (Figure 1). This design allowed to observe natural and reaction behaviours of the eight taxa under a range of environmental conditions. 
Figure 1. Study sites in the Bay of Biscay

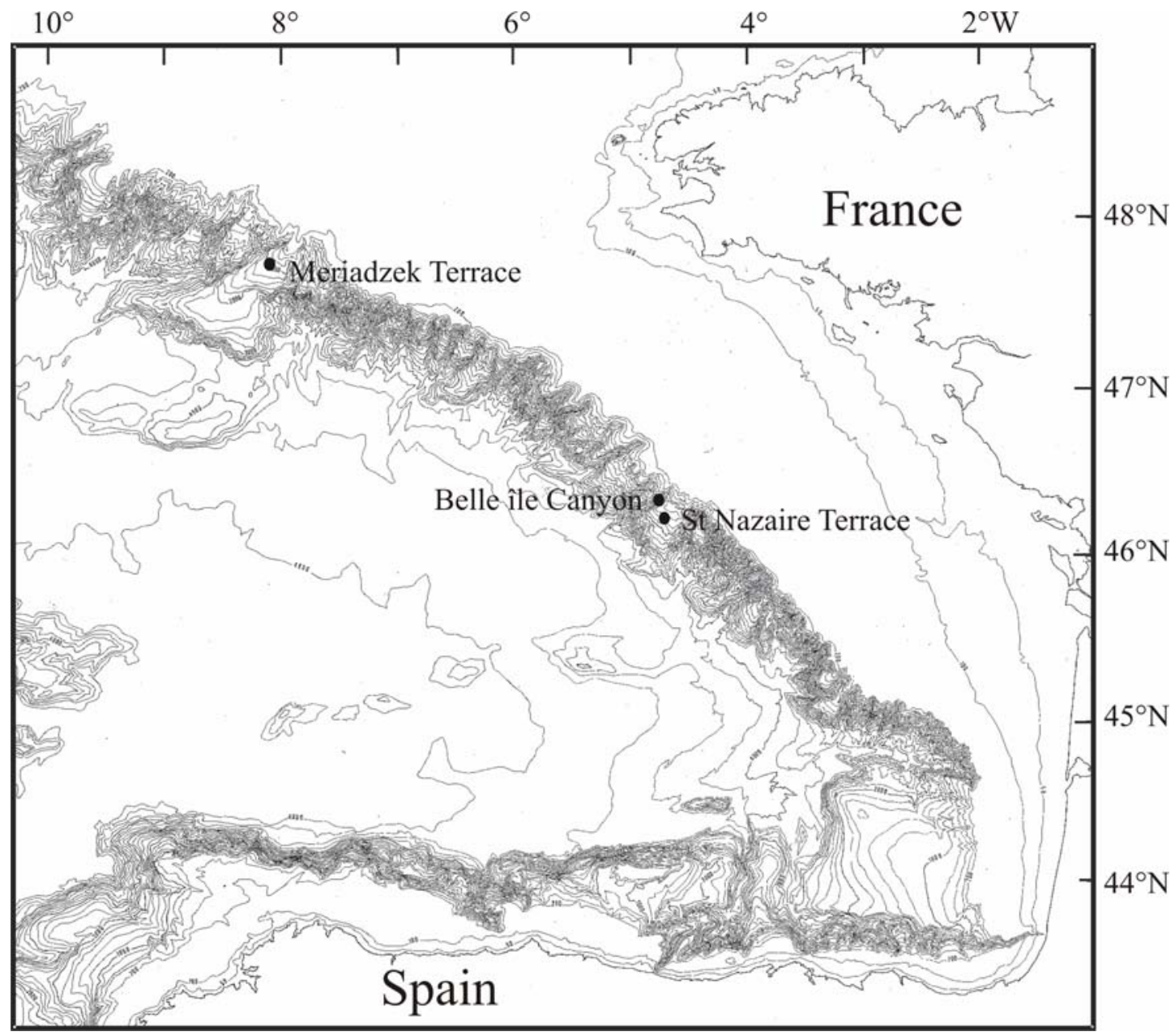




\section{Material and Methods}

\section{Data}

Population densities and ethology of near bottom deep-sea fish were studied with the ROV Victor 6000 at three sites on the continental slope, between 1100-1500 m, in the Bay of Biscay, August 2002 (Figure 1). Sites 1 and 2 were two flat terraces, and site 3 was a canyon. At all sites, research operations were identical and covered a 72 hour period (Trenkel et al. in press). Visual strip transects were carried out to assess fish population densities (Trenkel et al. 2004b). Environmental (temperature and bottom depth), and survey design (ROV distance from the bottom, speed, and direction) parameters were recorded simultaneously. Current speed and direction were measured continuously throughout the 72 hour period from a moored lander located at the deepest part of the survey area at each of the three sites. Observed instantaneous currents followed the tidal cycle and varied from 0 to $30 \mathrm{~cm} . \mathrm{s}^{-1}$.

The species considered were Aphanopus carbo, Coryphaenoides rupestris, Hoplostethus atlanticus and Trachyscorpia cristulata echinata. Individuals were grouped at family level for the Alepocephalidae, Chimaeridae, and Scyliorhinidae and at the order level for Squaliformes, where the families Centrophoridae and Dalatiidae were represented. For these supra-specific taxa, accurate in situ visual identification was not always possible and only a proportion of individuals belonging to these families were identified to species level (the species list is provided in Table 1). Based on a general description of natural (undisturbed) and reaction (disturbed) behaviour (Table 1), three categorical variables with four levels each were used to describe the natural behaviour of each individual fish. These variables were position in the water column, locomotion type, and activity level (Table 2). The position in the water column described the distance off the bottom the fish was in terms of number of body lengths. This metric was used because the ROV was not equipped with a system allowing for image scaling, although a small set of measures were collected using a laser system (Rochet et al. in press). Locomotion indicated what type of motion the fish carried out, while activity indicated how the fish carried out a particular motion. For example, a fish may drift (locomotion) completely passively (no body activity), or it may control the drift by fin movements. General reaction of each specimen to the approaching ROV was classified using two variables: reaction type and distance (Table 2). Reaction type had five categories ranging from no reaction to active movements. The reaction distance indicated whether individuals reacted before appearing in the observation field of the ROV, far from (while already seen) or at close distance to the ROV, or not at all. Reactions before first appearance were detected by arrival of individuals into the video field at high speed. In that particular case, the reaction type could not be categorised. 
Table 1. Single species and higher taxa studied together with description of their undisturbed and disturbed behaviour. For supra-specific taxa, the genera or species which one or several individuals were identified are listed.

\begin{tabular}{|c|c|c|}
\hline & undisturbed & disturbed \\
\hline Aphanopus carbo & $\begin{array}{l}\text { Swimming parallel to the } \\
\text { bottom or standing vertically } \\
\text { in the water possibly } \\
\text { alternatively swimming up } \\
\text { and slowly falling down to } \\
\text { the bottom }\end{array}$ & $\begin{array}{l}\text { Slow move away or burst } \\
\text { swim }\end{array}$ \\
\hline $\begin{array}{l}\text { Alepocephalidae } \\
\text { Alepocephalus bairdii } \\
\text { Alepocephalus rostratus }\end{array}$ & $\begin{array}{l}\text { Drifting passively high up in } \\
\text { the water column }\end{array}$ & Nervous start towards bottom \\
\hline $\begin{array}{l}\text { Chimaeridae } \\
\text { Chimaera monstrosa } \\
\text { Hydrolagus affinis } \\
\text { Hydrolagus mirabilis }\end{array}$ & $\begin{array}{l}\text { Station holding or slowly } \\
\text { swimming about } 1 \text { m off } \\
\text { bottom }\end{array}$ & $\begin{array}{l}\text { Active swim, nervous control } \\
\text { movements from all body, } \\
\text { lateral avoidance }\end{array}$ \\
\hline Coryphaenoides rupestris & $\begin{array}{l}\text { Station holding, Drifting or } \\
\text { swimming above bottom }\end{array}$ & $\begin{array}{l}\text { Active swim, may move } \\
\text { towards the bottom or swim } \\
\text { actively in front of the ROV }\end{array}$ \\
\hline Hoplostethus atlanticus & $\begin{array}{l}\text { Sitting/station } \\
\text { holding/drifting close to } \\
\text { bottom }\end{array}$ & $\begin{array}{l}\text { Flight avoidance towards } \\
\text { bottom, fast swim }\end{array}$ \\
\hline $\begin{array}{l}\text { Scyliorhinidae } \\
\text { Apristurus spp. }\end{array}$ & $\begin{array}{l}\text { Actively swimming high in } \\
\text { the water column }\end{array}$ & $\begin{array}{l}\text { Increased swimming activity, } \\
\text { changing direction }\end{array}$ \\
\hline $\begin{array}{l}\text { Squaliformes } \\
\text { Centrophoridae } \\
\text { Deania calcea } \\
\text { Dalatiidae } \\
\text { Dalatias licha } \\
\text { Centroscymnus coelolepis } \\
\text { Centroscymnus crepidater }\end{array}$ & $\begin{array}{l}\text { Slowly swimming high in the } \\
\text { water column }\end{array}$ & $\begin{array}{l}\text { Increased swimming speed, } \\
\text { changing direction, lateral } \\
\text { avoidance }\end{array}$ \\
\hline Trachiscorpia cristulata echinata & $\begin{array}{l}\text { Sitting, motionless often } \\
\text { associated to bottom feature, } \\
\text { stone, benthic fauna }\end{array}$ & $\begin{array}{l}\text { Short flight avoidance then } \\
\text { sits again }\end{array}$ \\
\hline
\end{tabular}


Table 2 Natural and reaction variables derived from ROV video observations.

\begin{tabular}{ll}
\hline Variable & Categories \\
\hline Natural behaviour & Sitting on bottom \\
Tosition in the water column & Less than 1 body length off bottom \\
& More than 1 body length off bottom \\
& No locomotion \\
& Station holding \\
& Drifting \\
& Forward movement/swimming \\
Locomotion & No activity \\
& Slight control movement from fins \\
& Strong control movement from fins \\
& Body movements to swim \\
Activity & No reaction \\
& Displays some reactive motion or change of attitude \\
& Increased activity or change in attitude but stays at the same place \\
& Moves in reaction to the ROV \\
Reaction behaviour & Disturbed arrival on the video screen \\
\hline Reaction type to the ROV & No reaction \\
Reaction at close distance (in the strongly illuminated area in front of the \\
ROV) \\
Reaction at far distance (while seen in the field of vision) \\
Before first appearance on the video screen \\
\hline
\end{tabular}

This categorisation of the fish behaviour relies upon assumptions of which behaviour is natural and which is disturbed. As natural behaviour, we only categorised behaviour according to three variables. Considering that an observed behaviour was natural, does not mean that an individual fish did not detect the ROV or did not change its vigilance level or any internal activity. However it implies that the fish did not change its behaviour before appearing in the video field (e.g. that fish sitting on the bottom or drifting were not swimming before detecting the ROV). The large number of observations in this study and in previous ones (Lorance et al., 2002; Uiblein et al., 2002, 2003) allowed for training and identification of what are the reactions of species and identification of clues of possible disturbance. As clues of reaction before first appearance on the video screen were taken, for example, conspicuous sediment plumes. Their absence allowed to ascertain that fish observed sitting had done so for some time and that those swimming had not just left the bottom. Lastly, some anecdotal observations helped us to build further our paradigm of natural behaviour of the studied species. Good examples of this are the observation of a drifting orange roughy during a stationary bait experiment with the ROV and cases where the arrival of the ROV or submersible from behind a feature (crest, cliff, roc) that hid the vehicle approach did not change the observed behaviour. Nevertheless, it should be considered that what is dealt with throughout this paper is an "assumed natural behaviour". 
The environmental variables were ambient water temperature, current speed at the mooring location, and depth. Survey design variables were ROV cruising speed and altitude above the sea floor (measured to the bottom of the ROV). The angle between the current direction and the ROV survey direction was used to create a variable indicating observations carried while surveying with the current (angle between current direction and ROV motion $\left.\leq 60^{\circ}\right)$, across the current $\left(>60^{\circ}\right.$ and $\left.<120^{\circ}\right)$, and against the current $\left(\geq 120^{\circ}\right)$.

The environmental parameters depth and water temperature were measured at the ROV while the current was measured at the lander. The distance between the two did not allow us to ascertain that the same current speed and direction prevailed. Therefore, the hypotheses that the current prevailing at the lander could be used as a proxy for the current at the ROV, was tested in the following way. At a given location, the internal tide induces cycles in current speed and direction, and water temperature (Trenkel et al., in press). Hence, the temperature varied for a few degrees over the tidal cycle during our experiments. For the temperature measured at the ROV the tidal variations combined with changing depth (Figure 2). The tidal cycle was very clear on the terraces (Figure 2a,b) and more disturbed in the canyon (Figure 2c). There was generally good correspondence between temperature recorded at the ROV and at the lander so that the related current cycles should have been similar.

In total 324 individuals of the studied species listed in Table 1 were observed. A small number of individuals appeared for too short a sequence or at too great a distance for complete categorisation hence the numbers of observations in the different analyses were slightly lower.

\section{Analysis}

Multiple correspondence analysis (MCA) was used to investigate the general relationship between taxon, natural and reaction behaviour, environmental variables, and survey design variables. The environmental (depth, temperature, current speed and direction) and survey design (ROV speed and direction) variables were treated as illustrative, which means that they were not included in the statistical treatment as such but only projected onto the axes. All these variables were tested as both continuous and categorical, with three categories for each variable.

Individuals with missing data for natural and reaction behaviour were excluded from the MCA as well as the taxon Aphanopus carbo which was represented by five individuals only, resulting in a data matrix of 291 individuals and six active variables. 
Figure 2. Water temperature recorded at the ROV (fine broken line) and at the lander (continuous bold line) at the three studied sites. The about $12 \mathrm{~h}$ cycle is due to the tide. The trends of increasing temperature over the all dives at the two first sites were due to decreasing depth during the dives, this did not appear at the third site as the ROV restarted 3 times from the lander depth. Moreover, at this site the topography probably interfered with the tidal cycle.

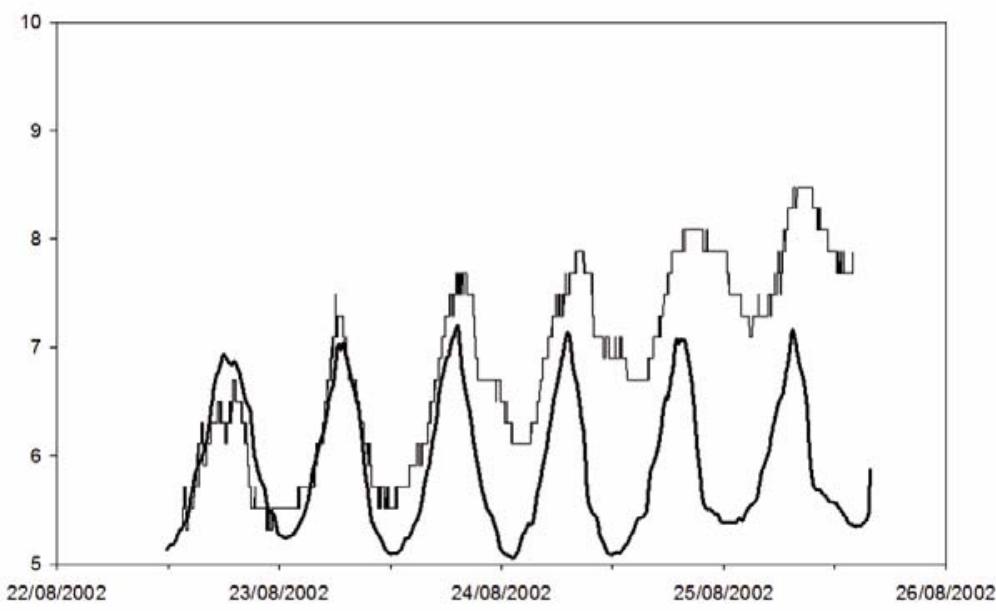

a)

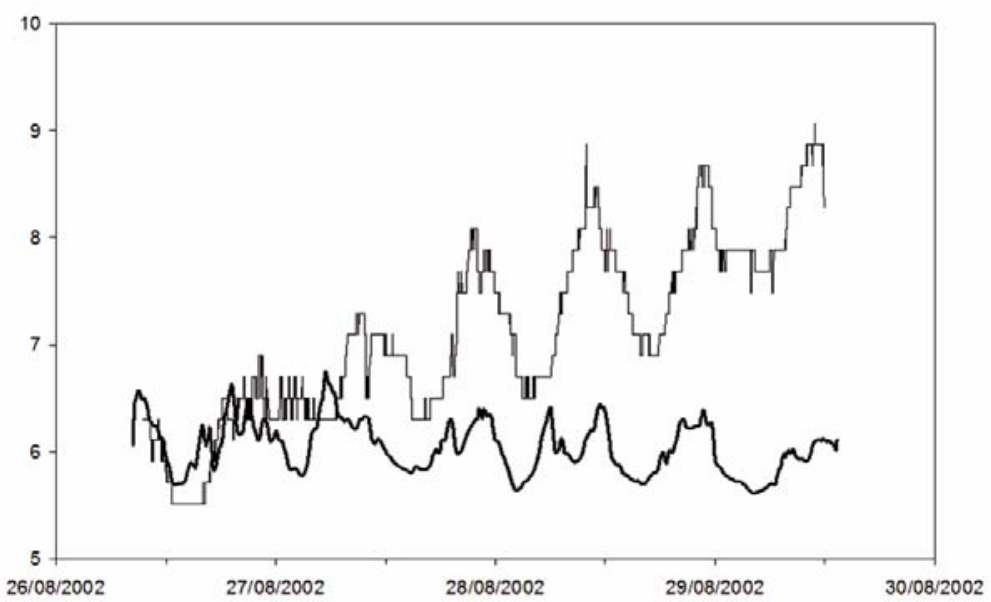

b)

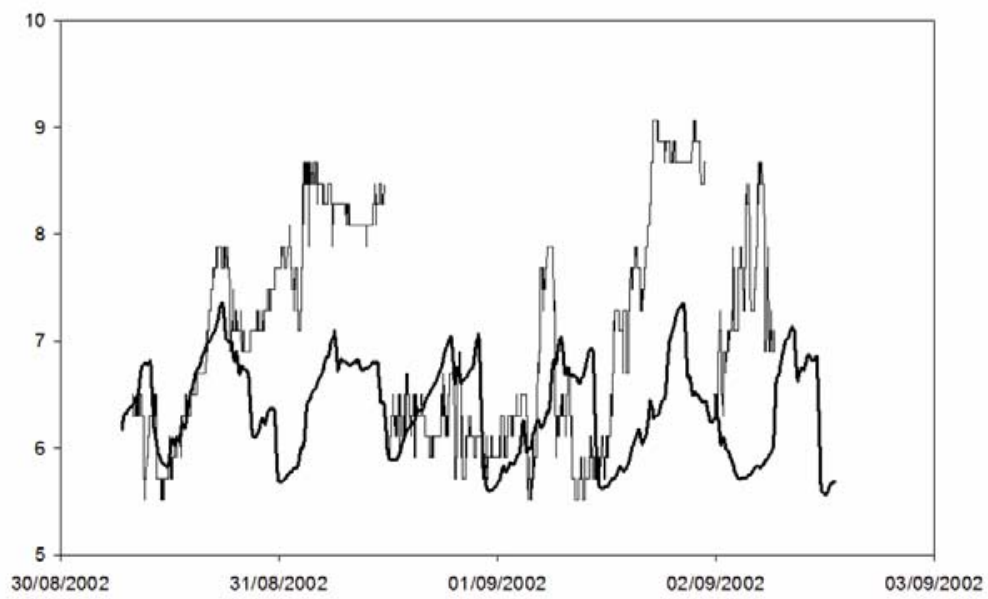

c) 
Moreover, the relationships between natural and reaction behaviour and environmental and survey design variables were explored separately for selected species. Individuals of a given species were sorted according to their locomotion type and reaction respectively using regression trees. Regression trees are an exploratory tool suitable for modelling categorical response variables using categorical explanatory variables (Breiman et al. 1984). Individuals are recursively split into two groups using the explanatory variables (here factor levels). At each node the split leading to the greatest difference in the response variable is selected. The final results are clusters of similar individuals. At each node the split leading to the greatest difference in the response variable is selected, and these splits are represented as branches of a tree. The leaf nodes of this tree are clusters of similar individuals. By looking at the values of the variables characterising each branch, a description of the final cluster is obtained. Locomotion type was chosen as the natural behaviour variable for the regression tree analysis as it might depend on environmental conditions. Explanatory variables tested were water temperature, depth and current speed. In addition, the position in the water column was included for obvious reasons, e.g. individuals sitting on the bottom cannot show any locomotion.

The reaction variable analysed was a combination of reaction type and reaction distance with three categories: no reaction, reaction before detection (appearing in view), and reaction after detection. The environmental variables were as stated above, water temperature, depth and current speed. The survey design variables were ROV speed over ground, ROV altitude, and observation angle (see data section).

\section{Results}

\section{Assumed natural behaviour and reaction by species}

A majority of individuals attributed to the species Aphanopus carbo (75\%), to the family Scyliorhinidae (87.3\%) and to the order Squaliformes (82.1\%) were observed swimming actively (Table 3). In contrast a majority of Alepocephalidae (70.6\%) were observed drifting and $100 \%$ of individuals belonging to the species Trachyscorpia. cristulata echinata were immobile while sitting on the sea floor. Chimaeridae, Coryphaenoides rupestris and Hoplostethus atlanticus displayed all four locomotion types to varying degrees, except $C$. rupestris which was never observed immobile.

About half the individuals of Alepocephalidae, C. rupestris and H. atlanticus reacted to the ROV at some point (Table 4). In contrast, nearly all Chimaeridae, Scyliorhinidae and Squaliformes and a few T. c. echinata reacted. As the reaction of $40 \%$ of the small $A$. carbo $(\mathrm{N}=5)$ sample was not interpretable, the result only indicate that this species occurs in small numbers close to the bottom and displays some reaction. 
Table 3. Natural behaviour: percentage of individuals observed per species per locomotion category.

\begin{tabular}{lrrrrr}
\hline Species & $\mathrm{N}$ & Immobile & Station holding & Drifting & Swimming \\
\hline Aphanopus carbo & 4 & 0.0 & 0.0 & 25.0 & 75.0 \\
Alepocephalidae & 17 & 0.0 & 29.4 & 70.6 & 0.0 \\
Chimaeridae & 51 & 3.9 & 51.0 & 7.8 & 37.3 \\
Coryphaenoides rupestris & 86 & 0.0 & 52.3 & 19.8 & 27.9 \\
Hoplostethus atlanticus & 20 & 10.0 & 50.0 & 30.0 & 10.0 \\
Scyliorhinidae & 71 & 4.2 & 7.0 & 1.4 & 87.3 \\
Squaliformes & 39 & 0.0 & 15.4 & 2.6 & 82.1 \\
Trachyscorpia cristulata & 19 & 100.0 & 0.0 & 0.0 & 0.0 \\
echinata & & & & & \\
\hline
\end{tabular}

Table 4. Number of individuals per reaction type to the ROV.

\begin{tabular}{lcrrrr}
\hline Species & N & No reaction & After detection & Before detection Not interpretable \\
\hline Aphanopus carbo & 5 & 40.0 & 20.0 & 0.0 & 40.0 \\
Alepocephalidae & 17 & 41.2 & 58.8 & 0.0 & 0.0 \\
Chimaeridae & 55 & 23.6 & 69.1 & 3.6 & 3.6 \\
Coryphaenoides rupestris & 90 & 43.3 & 51.1 & 2.2 & 3.3 \\
Hoplostethus atlanticus & 23 & 52.2 & 34.8 & 13.0 & 0.0 \\
Scyliorhinidae & 74 & 6.8 & 83.8 & 2.7 & 6.8 \\
Squaliformes & 41 & 24.4 & 56.1 & 7.3 & 12.2 \\
T. cristulata echinata & 19 & 89.5 & 10.5 & 0.0 & 0.0 \\
\hline
\end{tabular}

\section{Multi variate analysis}

The first two factors of the MCA represented respectively 19 and $15 \%$ of the total variance, i.e. $34 \%$ of the variance in the first factorial plane (Figure 3). This varied little when some changes were made in the variables used in the analyse (for exampled removing one of the reaction variables made almost no change as those variables were strongly correlated).

The MCA defined three species groups. Group 1 consisted of one single species, T.c. echinata, for which most individuals were seen completely inactive. This group was identified by the behavioural categories "Sitting" on the bottom, "No activity", "No locomotion". In terms of reactive behaviour, the species was characterised by "No reaction", however, this category was rather central in the factorial plane as, within other taxa, a proportion of individuals did not react to the ROV (Figure 3). This first group was strongly separated from the other two groups. Group 2 included $H$. atlanticus, C. rupestris and Alepocephalidae. These taxa were characterised by the categories "touching the bottom" to "less than one body length" from the bottom, "station holding" or "drifting" and "no" to "slight reaction" to the ROV. Group 3 was composed of Squaliformes, Scyliorhinidae and Chimaeridae and was associated to "more than 1 body length", "forward movement", "swimming" and "move in 
reaction to the ROV”. Clearly the MCA results reflect that these associations are not strict and that some modalities were intermediate between two groups rather than associated to only one particular group (e.g. the modality "No reaction" was intermediate between groups 1 and 2).

Figure 3. First factorial plane of MCA of natural behaviour and reaction to the ROV. Taxon ( $\mathbf{\square})$, Position in the water column $(+)$, Locomotion $(\diamond)$, Activity $(\diamond)$, Reaction type $(\bullet)$ Reaction distance $(\circ)$.

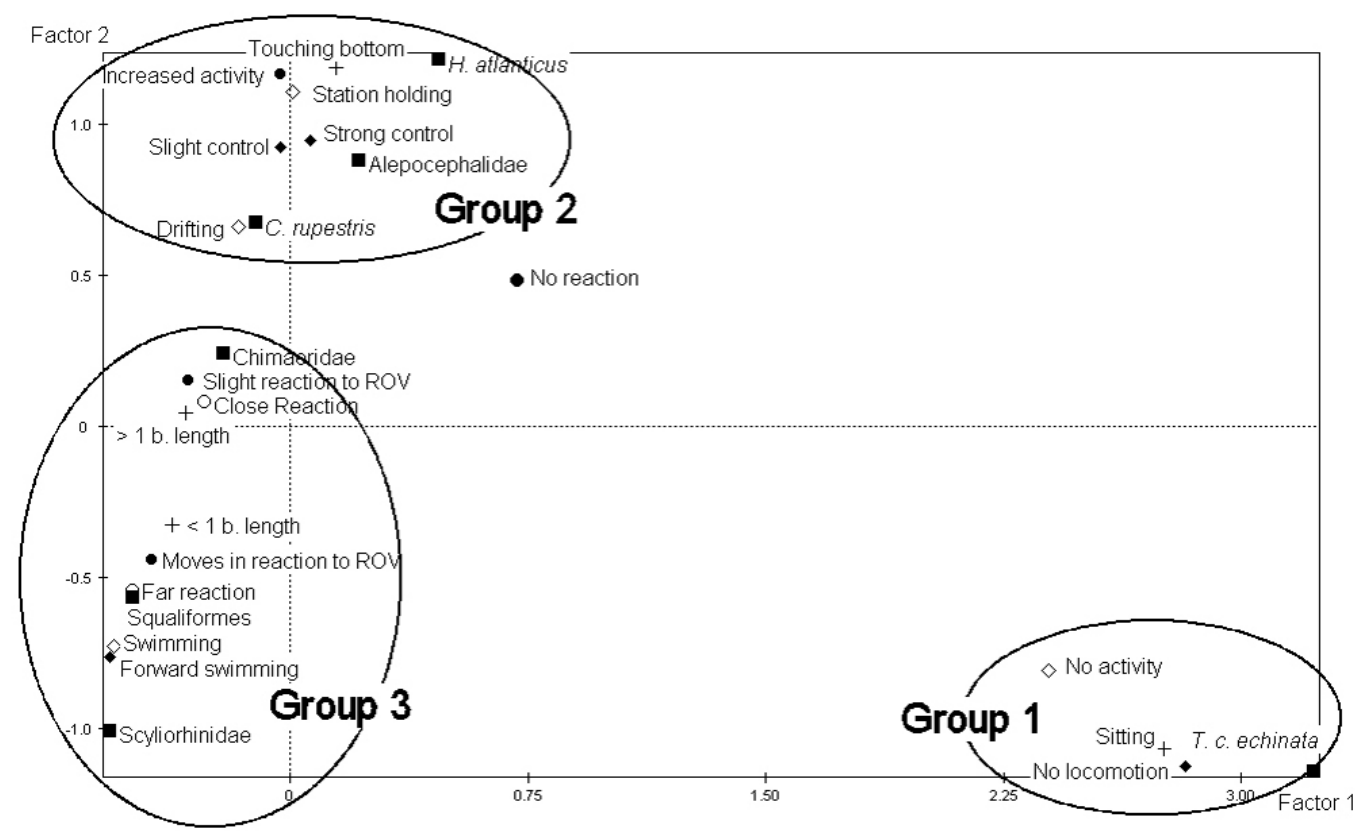

Shark species belonging to the Squaliformes order and the Scyliorhinidae family, tended to be higher in the water column, where they were observed to be swimming and often reacting to the ROV (sometimes reacting before detection). Chimaeridae appeared rather intermediate in their behaviour, most often reacting to the ROV and so resembling the sharks, but their assumed natural behaviour was closer to that of $C$. rupestris.

Considering the relationship between the behavioural variables, reaction to the approaching ROV was stronger and occurred earlier as the fish were initially seen to be higher in the water column and more active. Environmental variables were poorly correlated with the factors of the MCA indicating that there was no general relationship between behavioural and environmental factors common to all species.

\section{Single species analysis}

The regression tree analysis allowed the environmental variables to be ordered by levels of importance to explain locomotion behaviour for the three taxa showing varied locomotion types (Chimaeridae, C. rupestris and $H$. atlanticus). For 
Chimaeridae, position in the water column was most determining for the exhibited locomotion behaviour (Figure 4a). A majority (9/11) of Chimaeridae touching the bottom were holding station, as well as a majority (8/13) of individuals observed at some distance from the sea floor where current speed was low $\left(<6.2 \mathrm{~cm} . \mathrm{s}^{-1}\right)$, and a majority (7/12) from greater depths (below $1388 \mathrm{~m}$ ) where current speed was high. A majority of swimming Chimaeridae (10/19) were found in strong currents at shallower depths. In contrast, C. rupestris (Figure 4b) and H. atlanticus (Figure 4c) locomotion behaviour was explained by current speed. Strong currents $\left(>11.2 \mathrm{~cm} . \mathrm{s}^{-}\right.$ ${ }^{1}$ ) accounted for a majority (9/16) of $C$. rupestris showing drifting behaviour. Where current speed was lower, a majority (12/14) of C. rupestris sitting or touching the bottom were holding station and a majority (7/13) of individuals higher up from the bottom were holding station when the current speed was lowest. At intermediate currents velocity $\left(>5.2\right.$ and $<11.2 \mathrm{~cm} . \mathrm{s}^{-1}$ ) C. rupestris was observed swimming and holding station at both deep and shallow depths. For $H$. atlanticus, current speed was the only variable that had explanatory power; and individuals were predominantly holding station in strong currents $\left(>8.7 \mathrm{~cm} . \mathrm{s}^{-1}\right)$ or displaying all locomotion type behaviours in weaker currents. 
Figure 4. Regression trees for explaining locomotion type by behavioural and environmental variables for a) Chimaeridae, b) Coryphaenoides rupestris, c) Hoplostethus atlanticus. At each breakpoint the explanatory variable is indicated. Numbers at end points are number of individuals in each locomotion category: immobile/station holding/ drifting/swimming, most frequent categories are displayed in bold.

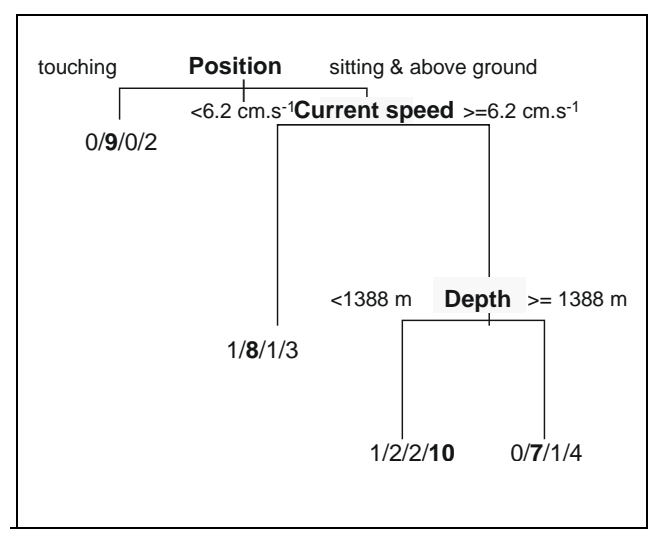

a)

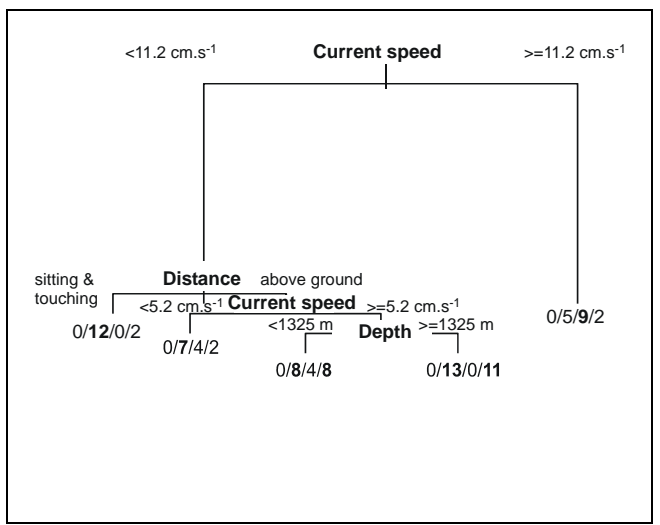

b)

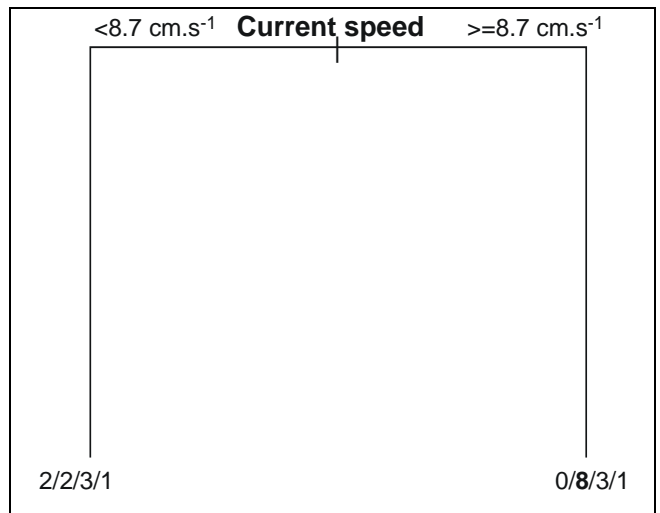

c) 
The regression analysis of the conditions under which studied species reacted to the ROV showed that strong currents $\left(>4.9 \mathrm{~cm} . \mathrm{s}^{-1}\right)$ and higher temperatures $\left(>6.2^{\circ} \mathrm{C}\right)$ resulted in a higher proportion of Chimaeridae to react to the approaching ROV (Figure 5a). A similar but weaker result was found for $H$. atlanticus (Figure 5c). Squaliformes were found to be more reactive at greater depths, below $1250 \mathrm{~m}$ (Figure 5d). The picture was more complex for C. rupestris (Figure 5b). Individuals primarily reacted when they were in higher temperatures $\left(>7.2{ }^{\circ} \mathrm{C}\right)$ and already swimming or drifting, or when the ROV was close to the sea floor $(<1.2 \mathrm{~m})$. By design the ROV was consistently held at about $0.8 \mathrm{~m}$ above the sea floor, unless uneven topography or strong currents required a higher altitude. No reaction behaviour occurred more often at the lower temperatures. The effect of ROV survey speed on fish reaction probability was unclear and seemed to have been linked to temperature.

Figure 5. Regression trees for explaining reaction distance by environmental and survey design variables for a) Chimaeridae, b) Coryphaenoides rupestris, c) Hoplostethus atlanticus, d) Squaliformes. At each breakpoint the significant explanatory variable is indicated. Numbers at end points are number of individuals in each reaction category: no reaction/after detection/before detection, most frequent categories are displayed in bold.

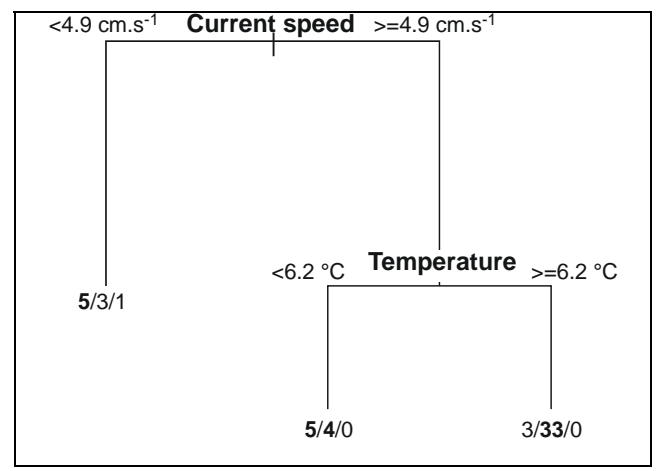

a)

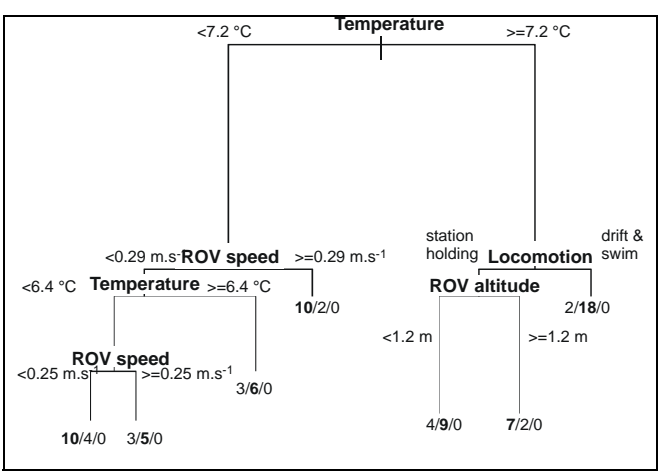

b)
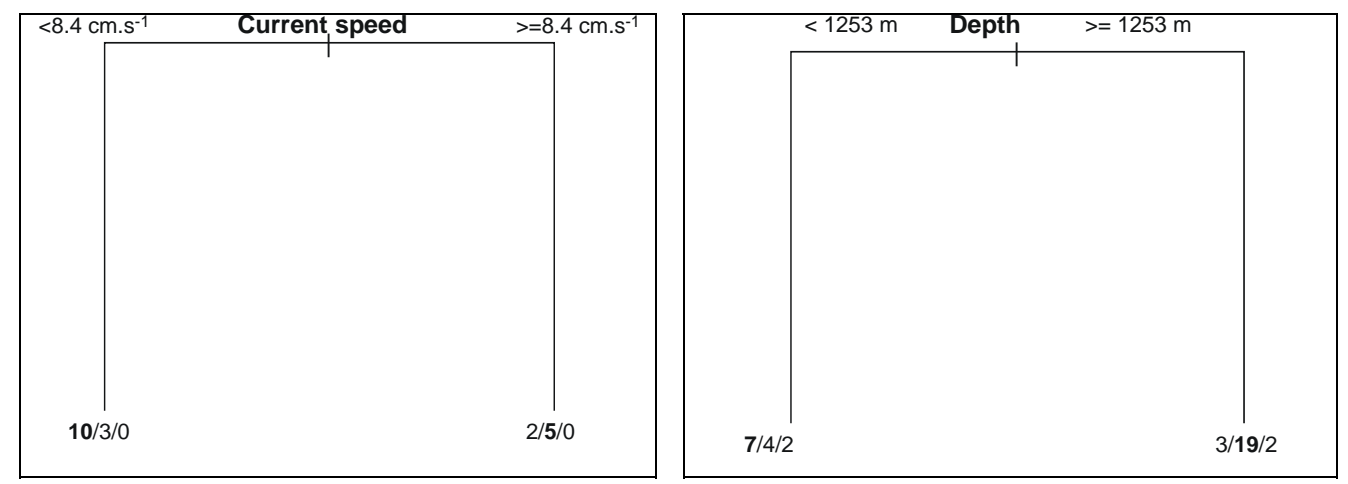


\section{Discussion}

\section{Behaviour and environment}

Single species analyses indicated that both the natural behaviour and the reaction to the ROV behaviour depended to some degree on environmental conditions. This environmental effect was also seen in a previous study for a different set of species (Uiblein et al. 2003). However, when all species were combined (MCA), no consistent effect of environmental conditions was evidenced. Hence adjustment to local or temporal conditions appears to be species-specific and different sets of variables appear to explain each species behaviour. The differences in locomotion types according to current and depth show that fish adjust their behaviour to both permanent (depth) and temporal (current) conditions. Reaction also varies according to these conditions, and effects may be direct, e.g. fewer reactions at greater depths for Squaliformes, or indirect, e.g. current speed that can induce a higher level of activity may be a factor for higher vigilance leading to higher reactivity.

\section{Representativeness of behaviour}

Our study showed that ROV speed and current direction relative to ROV motion may have an effect on the reaction for some species. However, most observation conditions were kept stable so that observed reactions might have depended upon the particular observation conditions. For example, in this study it was observed that Hoplostethus atlanticus and Coryphaenoides rupestris had similar reactions. However, in a previous study where approaches to these species were made at a closer distance to attempt catching and in situ tagging, only $H$. atlanticus could be caught in a scoop net manipulated by the submersible arm (Latrouite et al. 1999), while $C$. rupestris consistently kept some distance form the submersible. Hence, species that behaved in a similar way under our observation conditions may behave differently when other disturbances are introduced.

The same pair of species have illustrated in another study that observed behaviour may apply only to the habitat type where the observations were made. Koslow et al. (1995) observed far distance (>50 m) avoidance reactions for $H$. atlanticus in open water and interpreted this as an escapement behaviour from cetaceans. This avoidance behaviour was not seen in the present study, and it was speculated not be a useful behaviour response close to the bottom (Lorance et al. 2002) where a safe, resting habitat is available. When $H$. atlanticus occurs well off the bottom, this species might be more active (Koslow 1996), which implies higher detectability and hence far distance avoidance is to be expected. In contrast, C. rupestris might not display higher reactivity in the open water. An individual $C$. rupestris was observed at $75 \mathrm{~m}$ above the bottom during a previous submersible dive (Latrouite et al. 1999). This individual reacted at close distance from the submersible that was descending from the surface at less than $1 \mathrm{~m} \cdot \mathrm{s}^{-1}$ (P. Lorance, visual observation without video record). 
Some species were grouped at the family and order level for sample size reasons. However, the behaviour of these species might have some species-specificity. This was obvious for Squaliformes, within which, Deania calcea was seen swimming relatively fast and keeping a considerable distance from the ROV while Dalatias licha was swimming slowly, was closer to the bottom. and did not seem disturbed by the ROV. As behaviours are species specific, the results drawn at higher taxonomical level only provide an overview.

\section{Species life history}

The grouping of species from the MCA reflects common features shared by phylogenetically and ecologically distant species, however, if analysed at a more detailed level, species within the same MCA group can show different behaviours. In the MCA, Trachyscorpia cristulata echinata is clearly set apart. It is probably almost undetectable to predators due to its red colour, which is equivalent to black in the deep-sea environment (Merrett and Haedrich 1997), and its motionless sitting on the bottom behaviour. Thus, T. c. echinata showed little avoidance behaviour and most often did not react to the ROV. The reactivity of other species can be regarded as complementing their more active natural foraging strategy that implies a higher detectability. Most individuals of species belonging to group 2 of the MCA (Alepocephalidae, $C$. rupestris and $H$. atlanticus) were seen close to the bottom and their locomotion was characterised by drifting and moderate reaction to the ROV. Finally, the group 3 species are active hunters (sharks and chimaeras), that swim higher up in the water column and often show a strong reactive behaviour. Such reactions can be explained by the fact that these more active species are also more detectable by their predators, hence they are often required to be able to respond quickly. However, these reactions may also reflect the antagonistic and competitive behaviour within this group rather than an avoidance behaviour from potential predators.

The studied species are large and mobile predators of the mid-slope, they are also a potential prey of each other and of rare and larger deep-sea dwellers. Therefore, observed behaviour can be regarded as a trade off between foraging and predator avoidance (Hobson and Chess 2001).

Although the diet of T. c. echinata is unknown, we can infer from feeding habits of other Sebastidae and related Scorpaenidae, that it might consist of small fish and crustaceans ( Pallaoro and Jardas 1991; Bowman et al. 2000; Hobson and Chess 2001; Orlov and Abramov 2001). This assumed diet combined with the sit and wait behaviour implies an ambush predator (Table 6). Such a feeding strategy may involve several behavioural patterns. We only observed the "passive" phase, characterised by a minimisation of activity including a low exhalation rate (Laurenson et al. 2004), and some disturbance reaction, without witnessing actual feeding.

Alepocephalidae barely reacted to the approaching ROV, responding only at the last minute. This inherently slow reaction might be due to the fact that they are difficult to detect by a predator because of their dark colour and motionless drift. As well the neutral buoyancy of Alepocephalidae gained from a weak skeleton and watery body 
(Merrett and Haedrich 1997) may add to reducing detectability. Alepocephalidae feed on large and immobile gelatinous plankton and therefore would have a fairly passive feeding pattern, another factor contributing to this species slow response reaction. In the same MCA group, $C$. rupestris feeds on small pelagic crustaceans and $H$. atlanticus on large prey organisms, primarily fish, cephalopods and crustaceans (Mauchline and Gordon, 1984a,b; Rosecchi et al. 1988; Bullman and Koslow 1992). These prey species are known to occur tens to hundredths of meters off the bottom and display a diurnal vertical migration behaviour (Mauchline and Gordon, 1991). There is no known account of behaviour of Alepocephalidae and $C$. rupestris in the open water. Their morphology and low energetic rate suggest that they behave as drifters, waiting for an opportunistic encounter with their pelagic invertebrate prey (Mauchline and Gordon 1983a; Mauchline and Gordon 1984a; Mauchline and Gordon 1986). This weakly active pelagic foraging strategy would contrast with the active hunting necessary for $H$. atlanticus to feed on its larger and efficiently swimming prey.

The observed behaviour of the three chondrychthyan taxa (Squaliformes, Scyliorhinidae, Chimaeridae) may be linked to their active search for epibenthic or demersal food which is inferred from their diet (Table 6). "These [large sharks] fish consumers probably cruise above the surface of the seabed where they locate their prey" (Mauchline and Gordon 1983b). Deep-sea Chondrichthyans seem to be almost permanently searching for food although some Scyliorhinidae as well as some Chimaeridae may at times also display sitting or resting behaviour (Lorance et al. 2000).

Table 5. Eigenvalues and percent inertia associated to factors of the MCA

\begin{tabular}{cll}
\hline Rank & Eigenvalue & Percent inertia \\
\hline 1 & 0.6408 & 19.22 \\
2 & 0.4843 & 14.53 \\
3 & 0.3054 & 9.16 \\
4 & 0.2867 & 8.60 \\
5 & 0.2280 & 6.84 \\
6 & 0.2007 & 6.02 \\
7 & 0.1859 & 5.58 \\
8 & 0.1678 & 5.03 \\
9 & 0.1632 & 4.90 \\
10 & 0.1418 & 4.25 \\
11 & 0.1213 & 3.64 \\
12 & 0.0988 & 2.96 \\
13 & 0.0927 & 2.78 \\
14 & 0.0837 & 2.51 \\
15 & 0.0634 & 1.90 \\
16 & 0.0367 & 1.10 \\
17 & 0.0176 & 0.53 \\
18 & 0.0100 & 0.30 \\
19 & 0.0048 & 0.14 \\
20 & 0.0000 & 0.00 \\
\hline
\end{tabular}


Table 6 Relationship between observed behaviour, lifestyle and feeding strategy.

\begin{tabular}{|c|c|c|c|c|c|}
\hline Species & $\begin{array}{l}\text { Natural Locomotion } \\
\text { behaviour }\end{array}$ & $\begin{array}{l}\text { Distribution in the water } \\
\text { column }\end{array}$ & Main food & $\begin{array}{l}\text { Size of } \\
\text { preys }\end{array}$ & Lifestyle \\
\hline $\begin{array}{l}\text { Coryphaenoides } \\
\text { rupestris }\end{array}$ & $\begin{array}{l}\text { Station holding, drifting } \\
\text { or swimming }\end{array}$ & $\begin{array}{l}\text { Bottom to hundredths of } \\
\text { meters above }\end{array}$ & $\begin{array}{l}\text { Pelagic preys copepods, } \\
\text { amphipods, euphausiids } \\
(1,3)\end{array}$ & Small $(1,3)$ & $\begin{array}{l}\text { Benthopelagic. Feeds on } \\
\text { multispecies patches on diverse } \\
\text { preferred preys }(1,2,3)\end{array}$ \\
\hline $\begin{array}{l}\text { Hoplostethus } \\
\text { atlanticus }\end{array}$ & $\begin{array}{l}\text { Sitting, station holding, } \\
\text { drifting or swimming }\end{array}$ & $\begin{array}{l}\text { Bottom to hundredths of } \\
\text { meters above }\end{array}$ & Fish, decapods, squids (5) & Large $(1,5)$ & Opportunistic with preferred prey (1) \\
\hline Alepocephalidae & Drifting & $\begin{array}{l}\text { Bottom to tens of meters } \\
\text { above }\end{array}$ & $\begin{array}{l}\text { Diverse including } \\
\text { gelatinous fauna(1, 4) }\end{array}$ & Large (1) & $\begin{array}{l}\text { Benthopelagic. Opportunistic feeder } \\
\text { (1) }\end{array}$ \\
\hline T.c. echinata & Sitting & Bottom & $\begin{array}{l}\text { Small fish and crustacean } \\
\text { (6) }\end{array}$ & ? & Benthic ambush predator \\
\hline Aphanopus carbo & Swimming or drifting & $\begin{array}{l}\text { Bottoms to hundredth of } \\
\text { meters above }\end{array}$ & $\begin{array}{l}\text { Mesopelagic and } \\
\text { epipelagic fish (7) }\end{array}$ & Large (7) & Benthopelagic (7) \\
\hline Chimaeridae & $\begin{array}{l}\text { Station holding or } \\
\text { swimming }\end{array}$ & Close to bottom & Epibenthos (anemones) (8) & Small (8) & $\begin{array}{l}\text { Opportunistic feeder with preferred } \\
\text { prey(1) }\end{array}$ \\
\hline Scyliorhinidae & Actively swimming & Close to bottom & $\begin{array}{l}\text { Decapods (Sergestes spp.) } \\
\text { (8) }\end{array}$ & & Opportunistic with preferred prey (1) \\
\hline Squaliformes & Actively swimming & Close to bottom & Pisces $(1,8)$ & Large $(1,8)$ & Opportunistic feeder (1) \\
\hline
\end{tabular}

1: Mauchline and Gordon (1986); 2 Mauchline and Gordon (1985); 3 Mauchline and Gordon (1984a); 4: Mauchline and Gordon (1983a); 5: Bulman and Koslow (1992), Rosecchi et al. (1988); 6: Bowman et al. (2000), Hobson and Chess (2001), Orlov and Abramov (2001), Pallaoro and Jardas (1991); 7: Mauchline and Gordon (1984b), Dubuit (1978); 8: Mauchline and Gordon (1983b)

The distribution in the water column given here does not correspond to our observations in the near bottom environment but to the general literature and field knowledge. 
From the few data we have on Aphanopus carbo, this species displayed varied natural and reactive behaviour (Table 1). A. carbo occurs high up in the water column (Nakamura and Parin, 1993) and has fine swimming and sensory adaptations for predation on highly mobile prey (Bone 1971). The observed vertical and controlled drift or holding station from this study may correspond to one phase of its predatory behaviour inferred by Bone (1971).

As expected, each species displays a combination of life history traits, behaviour, food, habitat, in other words an ecological niche. The diversity of behaviour of midslope species is then both a response to the diversity of the energy pathways to this fish community, as described in Gordon (1979), as well as a mechanism allowing for numerous predators to co-occur in an energy poor environment.

\section{Consequences for fisheries management}

Knowledge of reaction behaviour can be used to evaluate as to whether a given species might be particularly vulnerable to trawling. Species such as Trachyscorpia cristulata echinata that do not react would be caught proportionally to the swept area of a the trawl. In contrast, species that show avoidance behaviour that forces them to swim ahead of the trawl or into the trawl path, will be herded by the net and consequently caught in higher numbers than those corresponding to their population density estimates. Hoplostethus atlanticus has been reported to be herded in front of a fishing trawl (Koslow et al. 1995; McClatchie et al. 2000). Our results suggest that, oryphaenoides rupestris might also be expected to be herded, given its observed avoidance behaviour towards the sea floor. Another consequence of the reaction behaviour is that population density estimates derived from trawling surveys using the swept area method might be seriously misleading in terms of relative species frequencies and densities, unless the actual swept area can be estimated correctly for each species. For the studied species, we can hypothesise that swept area estimates of densities might be correct for T.c. echinata, provide overestimates for C. rupestris and $H$. atlanticus that tend to herd in front of trawls, and may be underestimates for species that escape the trawl at far distance (some Squaliformes) or upwards (Aphanopus carbo). However, this conjecture remains speculative and needs to be confirmed by field studies, which unfortunately are costly at mid-slope depths.

Acknowledgements

We thank our colleagues, the pilots of the ROV Victor 6000, and the crew of R/V L'Atalante for assisting in the field data collection as well as our colleagues from the Deep-sea Ecosystem Department, IFREMER, Brest, for help with their video facilities. We are grateful to Dianne M. Tracey, NIWA, Wellington, and two anonymous referees for useful comments on the manuscript. 


\section{References}

Bailey, D.M., Priede, I.G., 2002. Predicting fish behaviour in response to abyssal food falls. Mar. Biol., 141(5), 831-840.

Bone, Q., 1971. On the scabbard fish Aphanopus carbo. J. Mar. Biol. Assoc. U.K., 51(1), 219-225.

Bowman, R.E., Stillwell, C.E., Michaels, W.L., Grosslein, M.D., 2000. Food of northwest Atlantic fishes and two common species of squid. NMFS-NE 155 NOAA Tech. Memo. 138 pp.

Breiman, L., Friedman, J.H., Olshen, R.A., Stone, C.J., 1984. Classification and regression trees. Wadsworth International Group, Belmont, Canada, 358pp.

Bulman, C.M., Koslow, J.A., 1992. Diet and food consumption of a deep-sea fish, orange roughy Hoplostethus atlanticus (Pisces: Trachichthyidae), off southeastern Australia. Mar. Ecol. Prog. Ser. 82(2), 115-129.

Cailliet, G.M., Andrews, A.H., Burton, E.J., Watters, D.L., Kline, D.E., FerryGraham, L.A., 2001. Age determination and validation studies of marine fishes: do deep-dwellers live longer? Exp. Gerontol., 36(4-6), 739-764.

Collin, S.P., Partridge, J.C., 1996. Retinal specializations in the eyes of deep-sea teleosts. J. Fish Biol. 49(Suppl. A), 157-174.

Du Buit, M.-H., 1978. Alimentation de quelques poissons téléostéens de profondeur dans la zone du seuil de Wyville Thomson. [The diet of some sea teleost fishes in the Wyville Thomson ridge area]. Oceanol. Acta 1(2), 129-134.

Gordon, J.D.M., 1979. Lifestyle and phenology in deep sea Anacanthine Teleosts. Symp. Zool. Soc. London 44, 327-359.

Gordon, J.D.M., 1986. The fish populations of the Rockall Trough. Proc. Royal Soc. Edinburgh 88B, 191-204.

Haedrich, R.L., Merrett, N.R., 1988. Summary atlas of deep-living demersal fishes in the North Atlantic Basin. J. Nat. Hist. 22(5), 1325-1362.

Hobson, E.S., Chess, J.R., 2001. Influence of trophic relations on form and behaviour among fishes and benthic invertebrates in some Californian marine communities. Environm. Biol. Fish., 60(4), 411-457.

Huston, M.A., 1994. Biological diversity, the coexistence of species on changing landscape. Cambridge University Press, Cambridge, U.K. 681pp.

Koslow, J.A., 1996. Energetic and life-history patterns of deep-sea benthic, benthopelagic and seamount-associated fish. J. Fish Biol. 49(Suppl.A), 54-74.

Koslow, J.A., Kloser, R., Stanley, C.A., 1995. Avoidance of a camera system by a deepwater fish, the orange roughy (Hoplostethus atlanticus). Deep-Sea Res. I 42(2), 233-244.

Latrouite, D., Désaunay, Y., De Pontual, H., Troadec, H., Lorance, P., Galgani, F., Bordalo Machado, P., Bavouzet, G., Noël, P., Véron, G., Danel, P., Dugornay, O., 1999. Compte-rendu de la campagne OBSERVHAL98 - Observations a finalité halieutique IFREMER Nantes, Brest, France. RST 99-01, 250 pp.

Laurenson, C.H., Hudson, I.R., Jones, D.O.B., Priede, I.G., 2004. Deep water observations of Lophius piscatorius in the north-eastern Atlantic Ocean by means of a remotely operated vehicle. J. Fish Biol, 65(4), 947-960.

Lorance, P., Latrouite, D., Seret, B., 2000. Observations of chondrichthyan fishes (sharks, rays and chimaeras) in the Bay of Biscay (North-eastern Atlantic) from 
submersibles. Proc. 3rd European Elasmobranch Association Meeting, Boulognesur-Mer, 27-29 May 1999, 29-45.

Lorance, P., Uiblein, F., Latrouite, D., 2002. Habitat, behaviour and colour patterns of orange roughy Hoplostethus atlanticus (Pisces: Trachichthyidae) in the Bay of Biscay. J. Mar. Biol. Assoc. UK 82(2), 321-331.

Mauchline, J., Gordon, J.D.M., 1983a. Diets of clupeoid, stomiatoid and salmonoid fish of the Rockall Trough. Marine Biol. 77(1), 67-78.

Mauchline, J., Gordon, J.D.M., 1983b. Diets of the sharks and chimaeroids of the Rockall Trough, northeastern Atlantic Ocean. Marine Biol., 75(2-3), 269-278.

Mauchline, J., Gordon, J.D.M., 1984a. Diets and bathymetric distributions of the macrourid fish of the Rockall Trough, northeastern Atlantic Ocean. Marine Biol. 81(2), 107-121.

Mauchline, J., Gordon, J.D.M., 1984b. Occurence and feeding of berycomorphid and percomorphid teleost fish in the Rockall Trough. ICES J. mar. Sci., 41(3), 239-247.

Mauchline, J., Gordon, J.D.M., 1985. Trophic diversity in deep-sea fish. J. Fish Biol., 26, 527-535.

Mauchline, J., Gordon, J.D.M., 1986. Foraging strategies of deep-sea fish. Mar. Ecol. Prog. Ser. 27(3), 227-238.

Mauchline J., Gordon J.D.M., 1991. Oceanic pelagic prey of benthopelagic fish in the benthic boundary layer of a marginal oceanic region. Mar. Ecol. Prog. Ser., 74, 109-115.

Mcclatchie, S., Thorne, R.E., Grimes, P., Hanchet, S., 2000. Ground truth and target identification for fisheries acoustics. Fish. Res. 47(2-3), 173-191.

Merrett, N.R., Haedrich, R.L., 1997. Deep-sea demersal fish and fisheries. Chapman and Hall, London, 282pp.

Musyl, M.K., Brill, R.W., Boggs, C.H., Curran, D.S., Kazama, T.K., Seki, M.P., (2003). Vertical movements of bigeye tuna (Thunnus obesus) associated with islands, buoys, and seamounts near the main Hawaiian Islands from archival tagging data. Fisheries Oceanography, 12(3), 152-169.

Nakamura I., Parin N.V., 1993. FAO species catalogue. Vol. 15. Snake mackerels and cutlassfishes of the world (families Gempylidae and trichiuridae). An annotated and illustrated catalogue of the snake mackerels, snoeks, escolar, gemfishes, sackfishes, domine, oilfish, cutlassfishes, scabbardfishes, hairtails and frostfishes known to date. FAO Fish. Synop. No. 125, 136pp.

Orlov, A.M., Abramov, A.A., 2001. Age, Rate of Sexual Maturation, and Feeding of the Shortraker Rockfish, Sebastes borealis (Scorpaenidae) in the Northwestern Pacific Ocean. Journal of Ichthyology/Voprosy Ikhtiologii, 41(4), 279-288.

Pallaoro, A., Jardas, I., 1991. Food and feeding habits of black scorpionfish (Scorpaena porcus L.1758) (Pisces, Scorpaenidae) along the Adriatic coast. Acta Adriatica, 32(2), 885-898.

Rochet, M.-J., Cadiou, J.F., Trenkel, V.M.,. in press. Precision and accuracy of fish length measurements obtained with two visual underwater methods. Fishery Bulletin. Rosecchi, E., Tracey, D.M., Webber, W.R., 1988. Diet of orange roughy, Hoplostethus atlanticus (Pisces: Trachichthyidae) on the Challenger Plateau, New Zealand. Marine biology, 99(2), 293-306.

Sibert, J.R., Muysl, M.K., Brill, R.W., (2003). Horizontal movements of bigeye tuna (Thunnus obseus) near Hawaii determined by Kalman filter analysis of archival tagging data. Fisheries Oceanography, 12(3), 141-151.

Simmonds, J., MacLennan, D.N., 2005. Fisheries acoustics, theory and practice. $2^{\text {nd }}$ ed., Blackwell Science, Oxford, 456pp. 
Trenkel, V.M., Bailly, N., Berthelé, O., Causse, R., De Corbière, F., Dugornay, O., Ferrant, A., Gordon, J.D.M., Latrouite, D., Le Piver, D., Kergoat, B., Lorance, P., Mahévas, S., Mesnil, B., Poulard, J.-C., Rochet, M.-J., Tracey, D., Vacherot, J.-P., Veron, G., Zibrowius, H., (in press) First results of a quantitative study of deep-sea fish on the continental slope of the Bay of Biscay: Visual observations and trawling. ICES Cooperative report.

Trenkel, V.M., Francis, R., Lorance, P., Mahevas, S., Rochet, M.-J., Tracey, D.M., 2004a. Availability of deep-water fish to trawling and visual observation from a remotely operated vehicle (ROV). Mar. Ecol. Prog. Ser. 284, 293-303.

Trenkel, V.M., Lorance, P., Mahevas, S., 2004b. Do visual transects provide true population density estimates for deepwater fish? ICES J. Mar. Sci. 61(7), 1050-1056. Uiblein, F., Lorance, P., Latrouite, D., 2002. variation in locomotion behaviour in northern cutthroat eel (Synaphobranchus kaupi) on the bay of Biscay continental slope. Deep-Sea Res. I, 49(9), 1689-1703.

Uiblein, F., Lorance, P., Latrouite, D., 2003. Behaviour and habitat utilisation of seven demersal fish species on the Bay of Biscay continental slope, NE Atlantic. Mar. Ecol. Prog. Ser. 257, 223-232.

Vangriesheim, A., 1985. Hydrologie et circulation profonde. In: Laubier L.,Monniot C. (eds) Peuplements profonds du golfe de Gascogne IFREMER Brest, France, 630pp.

Wagner, H.J., 2002. Sensory brain areas in three families of deep-sea fish (slickheads, eels and grenadiers): comparison of mesopelagic and demersal species. Marine Biol. 141(5), 807-817.

White, B.N., 1988. Titre Oceanic anoxic events and allopatric speciation in the deep sea. Biol. Oceanogr. 5(4), 243-259. 